\title{
Effect of altered extracellular magnesium concentration on the neuronal activity in different hippocampal regions of immature rats
}

\author{
A. Vlasiuk, A. Romanov, D. Isaev, E. Isaeva \\ O.O.Bogomoletz Institute of Physiology of National Academy of Science of Ukraine, Kyiv; \\ e-mail: olena.isaeva@gmail.com
}

\begin{abstract}
Using acute hippocampal slice preparation dissected from immature rats, we investigated the effect of lowering $\mathrm{Mg}^{2+}$ concentration in the extracellular solution on the probability to evoke epileptiform activity in different regions of hippocampus. Electrophysiological recordings revealed different patterns of such activity in hippocampal CA1 region. In agreement with studies on the adult rat hippocampus probability to induce epileptiform activity by means of lowering $\mathrm{Mg}^{2+}$ concentration was increased in the ventral part of hippocampus $(\mathrm{VH})$ compared to dorsal part $(\mathrm{DH})$. We also found a significant increase in probability to induce ictal-like activity (ILE) in both hippocampal regions compared to results obtained in adult rats with a higher rate of ILE incidence in VH (90\%) compared to DH (50\%). Our experiments with cuts of hippocampal fiber pathways showed that in VH, ILE originated in CAI region and propagated to CA3 region and dentate gyrus, while interictal-like activity originated in CA3 region. Possible mechanisms of the region specificity of the development of epileptiform activity in the immature hippocampus discussed. Key words: epileptiform activity; dorsal and ventral hippocampus; immature rat.
\end{abstract}

\section{INTRODUCTION}

Temporal lobe epilepsy (TLE) is the most common type of partial epilepsy [1]. TLE is associated with a high mortality rate and various psychiatric and behavioral comorbidities [2]. The histopathological studies suggest that different temporal lobe regions, including the hippocampus, are frequently damaged in human drug-refractory TLE [3]. It was shown that the surgical removal of hippocampus results in a decrease or complete cessation of seizures [3]. These data reveal a crucial role of this structure in pathophysiology of TLE. So understanding the mechanisms of generation and propagation of seizure activity in the hippocampus is of key importance in the antiepileptic drug discovery.

Although in the majority of epilepsy research studies the hippocampus is regarded as a unitary structure, there are a lot of evidences suggesting that separate parts of hippocampus

(C) A.Vlasiuk, A. Romanov, D. Isaev, E. Isaeva have substantial difference in molecular, cellular and histological organization and, as a result, play distinctive functional roles [4]. Regional differences in susceptibility to seizure generation as well as sensitivity to seizure-induced damage was also reported when studied in the adult animals [5-7]. It was shown that ventral hippocampus (VH) is more vulnerable to the abnormal synchronization and dorsal part of hippocampus $(\mathrm{DH})$ is more resistant to seizureinduced injury and neuronal death than $\mathrm{VH}$ $[5,6,8,9]$. The difference in seizure susceptibility of DH and $\mathrm{VH}$ could be at least partly explained by the difference in the receptor expression in different parts of hippocampus $[8,10]$.

It is well established that the immature brain is more susceptible to seizures compared to the adult brain. Among the factors, which may contribute to the increased vulnerability of immature brain to seizure generation, are developmental changes in the expression and 
molecular composition of glutamate receptors and maturation of functional properties of $\mathrm{GABA}_{\mathrm{A}}$ receptors. We hypothesized that neuronal network excitability in $\mathrm{VH}$ and $\mathrm{DH}$ in the immature brain may differ from that one reported in the mature brain. To test this hypothesis in the present study we examined the regional differences in susceptibility to seizure generation between the $\mathrm{VH}$ and $\mathrm{DH}$ of immature rats. Using an acute hippocampal slice preparation dissected from rats at postnatal ages 12-14, we investigated the effect of lowering $\mathrm{Mg}^{2+}$ concentrations in the extracellular solution on the probability to evoke seizure-like activity, its delay time and patterns of discharges in different parts of hippocampus.

\section{METHODS}

All experimental procedures were performed in accordance with the guidelines set by the National Institute of Health for the humane treatment of laboratory animals and approved by the Animal Care Committees of Bogomoletz Institute of Physiology. Wistar rats (postnatal day 12-14) were deeply anesthetized using sevoflurane, decapitated, and both hippocampi were dissected out from the brain immersed in cold $\left(2-4^{\circ} \mathrm{C}\right)$ carboxygenated $\left(95 \% \mathrm{O}_{2}\right.$ and $5 \% \mathrm{CO}_{2}$ ) artificial cerebrospinal fluid (ACSF) of the following composition (mmol/l): $\mathrm{NaCl}$ 125, $\mathrm{KCl} 3.5, \mathrm{CaCl}_{2} 2.0, \mathrm{MgCl}_{2} 1.3, \mathrm{NaHCO}_{3}$ $24, \mathrm{NaH}_{2} \mathrm{PO}_{4} 1.25$ and glucose $11(\mathrm{pH} 7.35)$. Hippocampal slices $(400 \mu \mathrm{m})$ were prepared using a vibroslicer and then held submerged in oxygenated ACSF at room temperature (22-240 C) for at least 1.5 hours before the transfer to the recording chamber.

For experiments the $2^{\text {d }}$ to $4^{\text {th }}$ slices from dorsal and ventral ends of hippocampus (DH and $\mathrm{VH}$ ) were used. Slices were placed in the recording chamber and perfused with oxygenated $\operatorname{ACSF}\left(2 \mathrm{ml} / \mathrm{min}, 30^{\circ} \mathrm{C}\right)$. All experiments were started 10-15 min after transferring slices into recording chamber to allow equilibration of the temperature inside the slice. Extracellular field potential recordings were obtained from pyramidal CA1, CA 3 regions and dentate gyrus (DG) using glass microelectrodes filled with ACSF (1-2 M $\Omega$ ). The signals were filtered between $0.1 \mathrm{~Hz}$ and $1 \mathrm{kHz}$ using differential amplifier (A-M Systems 1700, Sequim, WA, USA). Epileptiform activity (EA) was induced by application of modified ACSF of the following composition (mmol/l): $\mathrm{NaCl} 125, \mathrm{KCl}$ 3.5, $\mathrm{CaCl}_{2} 2.0, \mathrm{NaHCO}_{3} 24, \mathrm{NaH}_{2} \mathrm{PO}_{4} 1.25$ and glucose 11 ( $\mathrm{pH} 7.35)\left(\mathrm{Mg}^{2+}\right.$-free solution). We did not observed EA in any slices before the application of pro-epileptic solution.

Data were analyzed using Origin 7.5 (Microcal Software, Northampton, MA, USA) software. The proportion of slices with and without EA was compared using the Fisher's exact test. The difference between means was compared using Student's t-test.

\section{RESULTS AND DISCUSSION}

Perfusion of hippocampal slices with $\mathrm{Mg}^{2+}$ -free solution evoke EA. Field potential recordings from hippocampal CA1 layer were used to compare EA from DH and VH slices. Two patterns of EA induced by $\mathrm{Mg}^{2+}$-free solution were observed in both $\mathrm{DH}$ and $\mathrm{VH}$ slices: ictal-like events (ILE) and interictal-like epileptiform discharges (IED) (Fig. 1A, B). IED had spontaneous nature with changing frequency throughout the application of $\mathrm{Mg}^{2+}$-free solution (data not shown). ILE were characterized by the similar frequency and time between bursts in precise slice (data not shown). Extracellular recordings showed that $65 \%$ of $\mathrm{VH}(\mathrm{n}=20)$ slices generated EA under $\mathrm{Mg}^{2+}$-free conditions, compared to $28.6 \%$ of $\mathrm{DH}(\mathrm{n}=21)$ slices $(\mathrm{P}=0.05$, Fig. 1C). Data obtained for the VH slices showed a higher rate of ILE incidence (90\%) compared to $50 \%$ in DH slices while no regional difference was observed in occurrence of IED (60\% in VH slices vs $66.7 \%$ in $\mathrm{DH}$ slices, Fig. 1D).

The onset of EA in VH $(10 \pm 4 \mathrm{~min})$ was faster than in $\mathrm{DH}(23 \pm 10 \mathrm{~min})(\mathrm{P}<0.01)$. 
Restoring normal ACSF after one hour of exposure of slices to $\mathrm{Mg}^{2+}$-free solution resulted in the complete suppression of EA in all DH and $\mathrm{VH}$ slices. Ictal activity had a varying frequency between slices from 4 to $10 \mathrm{~Hz}$ and ictal bursts occurred every 2-10 min with no difference between recordings from $\mathrm{DH}$ and $\mathrm{VH}$ slices. IED occurred with a low frequency from 0.01 to $0.09 \mathrm{~Hz}$ no difference were observed in both hippocampal regions.

Considering a higher probability of VH to generate ILE, we performed a series of fiber pathways cuts in VH to understand better an origin of ictal-like activity in CA1 region of hippocampus (Fig. 2). ILE was evoked by application of low $\mathrm{Mg}^{2+}$ solution in the intact $\mathrm{VH}$ slice and recording was made simultaneously from CA1, CA3 and DG regions (Fig. 2A). After first cut through Shaffer collaterals original ILE disappeared in all regions and new patterns of activity developed: ILE in CA1 and IED in CA3 regions (Fig. 2B). DG expressed both patterns of activity simultaneously with CA1 and CA3. Isolated $\mathrm{CA} 1$ continued to generate the same pattern of ILE (Fig. 2C). Frequency of ILE in CA1 region changed slightly from 5 to $4 \mathrm{~Hz}$ after the first cut while average time between bursts (6 min) remained unchanged. Cut through mossy fibers revealed that separated DG did not generate EA in a response to the application of low $\mathrm{Mg}^{2+}$ solution (Fig. 2D). These data indicate that in VH, ILE originates in CA1 region and propagates to $\mathrm{CA} 3$ and $\mathrm{DG}$, where it seems to have a suppressive action on IED. IED origina-

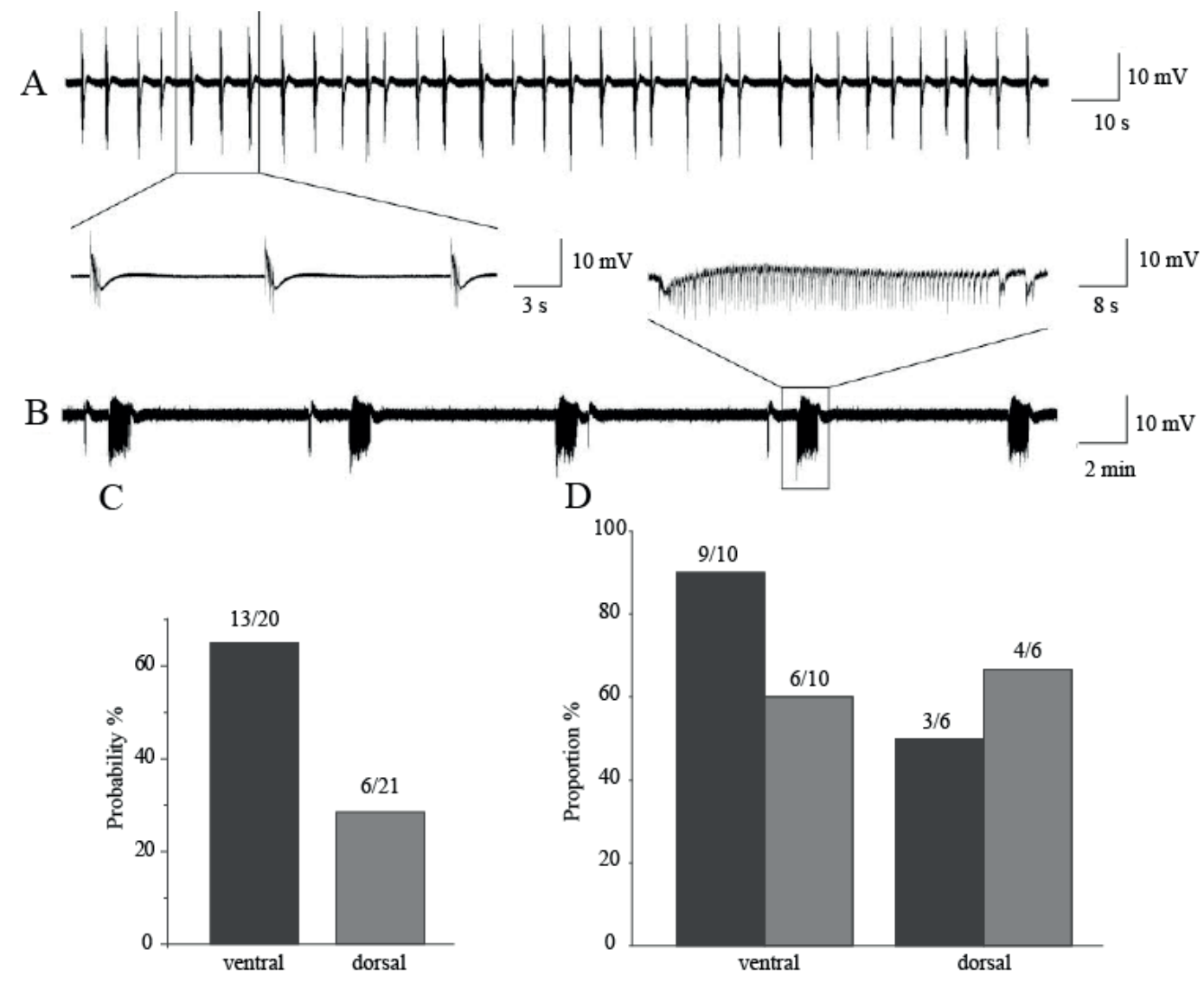

Fig. 1. Epileptiform activity (EA) induced by $\mathrm{Mg}^{2+}$-free solution in $\mathrm{VH}$ and DH slices. Example of evoked interictal epileptiform discharges (IED) in VH slice (A) and ictal-like events (ILE) generated in DH slice (B) with parts of traces on an expanded time scale. C. Probability of EA induction in VH (1) and DH (2). D. Proportion of ILE (black) and IED (grey) evoked in VH and DH. Number of slices used for experiments are indicated above the each column 
tes in CA3 region and invades to DG.

Although regional specificity of hippocampal formation to generate EA has been studied extensively, surprisingly little is known about seizure susceptibility of different regions of hippocampus in the immature rats. Our data show that the $\mathrm{VH}$ is more vulnerable to seizure generation compared to its dorsal counterpart in immature animals. These data are in agreement with previous studies conducted on the adult animals [7]. In our study the propensity to generate ILE in both hippocampal regions of

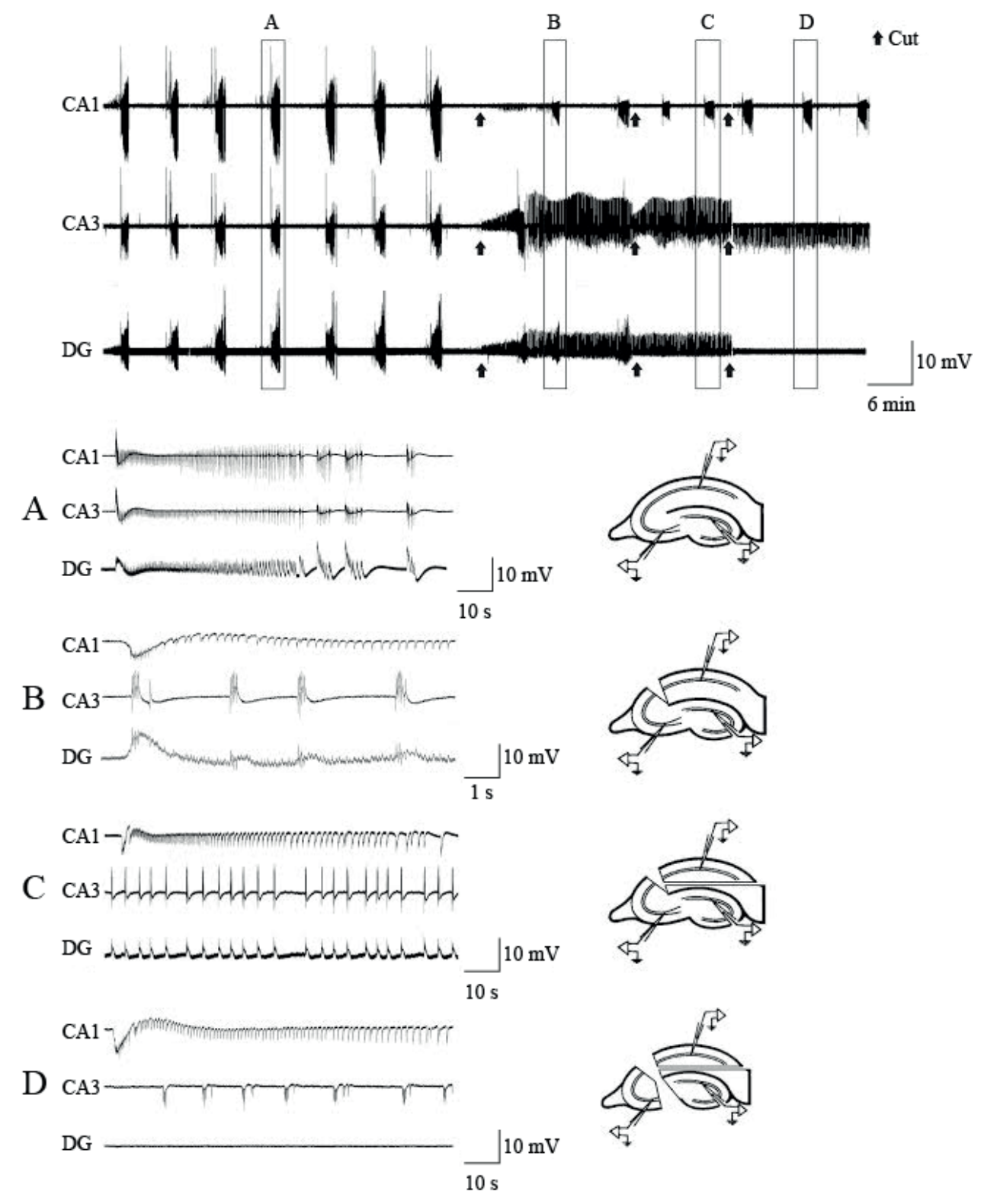

Fig. 2. Effects of fiber pathways cuts in VH on the propagation of ILE. The top panel shows simultaneous extracellular recordings from hippocampal CA1, CA3 and DG regions with arrows specifying of cut locations. Representative recording of ILE induced by $\mathrm{Mg}^{2+}$-free solution in the intact hippocampal slice (A) and in the slice with a cut through the Schaffer collaterals (B). Note that in the latter case ILE occured in CA1 while EA of CA3 was changed to IED. At the same time, DG expressed both activities together. C. When CA1 area had been severed from the rest of the slice, IED remained coupled with CA3 region and DG. D. The separated DG area did not generate any EA 
immature animals was higher compared to one previously obtained for adult rats [7]. Also $\mathrm{VH}$ demonstrate a higher rate of ILE incidence compared to $\mathrm{DH}$. To induce EA in our study we used a low $\mathrm{Mg}^{2+}$ solution. Lowering $\mathrm{Mg}^{2+}$ in an extracellular solution has been shown to create a hyperexcitable environment conducive for seizure generation by decreasing membrane surface charge screening, lowering $\mathrm{Mg}^{2+}$. sensitive $\mathrm{Ca}^{2+}$ channel block, and decreasing the $\mathrm{Mg}^{2+}$ blockade of N-methyl-D-aspartate (NMDA) receptors [11-13]. Although, lower levels of mRNA and protein expression for NR2A, NR2B subunits was reported in CA1 region of $\mathrm{VH}$, compare to $\mathrm{CA} 1$ region of $\mathrm{DH}$ [10], it was suggested that in the low $\mathrm{Mg}^{2+}$ model of ictogenesis the contribution of NMDA receptors was greater in $\mathrm{VH}$ than in $\mathrm{DH}$ in adults rats [5]. This discrepancy could be at least partly explained by the difference in the ratio of NMDA receptor subunits NR2A and NR2B in VH and DH [10], with NR2A subunit prevailing in the $\mathrm{DH}$. The decreased ratio of NR2A/NR2B in VH compared to $\mathrm{DH}$ implies the prolongation of the decay time of the NMDAR-mediated synaptic current and a weaker sensitivity of the NMDA receptor channel to $\mathrm{Mg}^{2+}$ [14]. It is known that in the immature brain, a ratio of NR2A/NR2B in hippocampal neurons is increased compared to one in adult rats [14]. We suggest that developmental changes in the NMDA receptors subunit composition can at least partly explain the increased probability to ILE induction in the immature hippocampus. Increased expression of AMPA receptor and underdeveloped inhibitory synaptic system in the immature brain could be among other contributing factors [15].

Previous studies indicate that the origin of seizure-like activity onset may depend on the postnatal age [16]. Our experiments reveal that both $\mathrm{CA} 1$ and $\mathrm{CA} 3$ regions in $\mathrm{VH}$ are able to produce the EA in response to the $\mathrm{Mg}^{2+}$ free solution. In the intact slice ILE occurs simultaneously in both CA1 and CA 3 regions. However, our experiments with cuts of fiber pathways show that, when separated, CA1 and CA3 regions express different patterns of activity. ILE originates in CA1 region and propagates to CA3 and DG, while IED originates in CA3 region and invade to DG. Using $\mathrm{Mg}^{2+}$ free model of seizure-like activity in 22-32 days old rats Lewis et al. [17] have obtained very similar results. They showed that low $\mathrm{Mg}^{2+}$. induced interictal-like activity originates in an area $\mathrm{CA} 2-3$ and propagates to area CA1, and CA1 did not generate the interictal-like activity when isolated from CA2-3, but produced ILE more readily than CA2-3 [17]. A cellular mechanism of development of ictal-like activity in CA1 region is not completely understood. It has been recently reported that different forms of $\mathrm{Mg}^{2+}$-free induced EA in CA1 region of hippocampus have a different sensitivity to NMDA receptor antagonists [18]. ILE can be blocked by application of D-APV. In contrast, NMDA antagonist does not affect interictal activity (late recurrent interictal discharges) [18]. Also it has been reported that there is a greater expression of $\mathrm{NR} 2 \mathrm{~B}$ in the $\mathrm{CA} 1$ region compare to the CA3 or DG [20]. As NR2B subunit has a greater affinity for glutamate, also it is more selective to $\mathrm{Ca}^{2+}$ entry, and has slower desensitization than NR2A subunit [20], we hypothesize that the increased expression of this subunit of NMDA receptors in CA1 neurons, at least partly, may contribute to the development of ILE in this region of hippocampus.

\section{А. Власюк, А. Романов, Д. Ісасв, О. Ісасва \\ ВПЛИВ ЗМІН ПОЗАКЛІТИННОЇ КОНЦЕН- ТРАЦІЇ МАГНІЮ НА НЕЙРОННУ АКТИВ- НІСТЬ У РІЗНИХ ДІЛЯНКАХ ГІПОКАМПА МОЛОДИХ ЩУРІв}

Досліджували вплив зниження концентрації $\mathrm{Mg}^{2+}$ у позаклітинному розчині на ймовірність ініціації епілептиформної активності в різних зонах гіпокампа щура. Електрофізіологічні дослідження показують різний характер епілептиформних явищ в зоні CA1 гіпокампа. Відповідно до експерементальних результатів, отриманих на моделі дорослих щурів, у дослідженнях на молодих щурах вірогідність виникнення епілептиформної активності в вентральній частині гіпокампа була вище, ніж у дорсальній. Також було показано істотне підвищення 
ймовірності ініціації іктальноподібної активності в обох зонах гіпокампа щодо значень у дорослих щурів. При цьому вірогідність виникнення епілептиформної активності у вентральних зрізах була вище порівняно $з$ дорсальними зрізами на $40 \%$. Наші експерименти з розрізанням провідних шляхів показують, що іктальноподібна активність у вентральних зрізах виникає в зоні СА1 і поширюється в зону СА3 і зубчасту звивину, водночас інтеріктальна активність бере початок в зоні СА3. Механізми генерації епілептиформної активності в різних зонах гіпокампа молодих щурів потребують подальших досліджень. Ключові слова: епілептиформна активність; дорсальна і вентральна ділянки гіпокампа; молоді щури.

Інститут фізіології ім. О. О. Богомольияя Національної академії наук України, Київ

\section{А. Власюк, А. Романов, Д. Исаев, Е. Исаева ВЛИЯНИЕ ИЗМЕНЕНИЙ ВНЕКЛЕТОЧ- НОЙ КОНЦЕНТРАЦИИ МАГНИЯ НА НЕЙРОН- НУЮ АКТИВНОСТЬ В РАЗЛИЧНЫХ УЧАСТ- КАХ ГИППОКАМПА МОЛОДЫХ КРЫС}

Исследовали влияние снижения концентрации $\mathrm{Mg}^{2+}$ во внеклеточной растворе на вероятность инициации епилептоподобной активности в различных зонах гиппокампа крысы. Электрофизиологические исследования показывают различный характер эпилептоформных явлений в зоне СА1 гиппокампа. Согласно экспериментальным результатам, полученным на модели взрослых крыс, вероятность возникновения епилептоподобной активности в вентральной части гиппокампа выше, чем в дорсальной. Также было показано существенное повышение вероятности возникновения иктальноподобной активности в обеих зонах гиппокампа по сравнению с значениями, полученными на взрослых крысах. При этом вероятность инициации епилептоподобной активности в вентральных срезах была выше относительно дорсальных срезов на $40 \%$. Наши эксперименты с перерезанием проводящих путей показывают, что иктальноподобная активность в вентральных срезах возникает в CA1 зоне и распространяется в зону СА3 и зубчатую извилину, в то время как интериктальная активность берет начало в зоне САЗ. Механизмы возникновения эпилептиформной активности в различных зонах гиппокампа молодых крыс требуют дальнейших исследований.

Ключевые слова: эпилептиформная активность; дорсальные и вентральные отделы гиппокампа; молодые крысы.

\section{REFERENCES}

1. Téllez-Zenteno JF and Hernández-Ronquillo L. A Review of the Epidemiology of Temporal Lobe Epilepsy. Epilepsy Res Treat. 2012; 1-5.

2. Curia G, Lucchi C, Vinet J, Gualtieri F, Marinelli C, Torsello A, Costantino L, and Biagini G. Pathophysiogenesis of mesial temporal lobe epilepsy: is prevention of damage antiepileptogenic? Curr Med Chem. 2014; 21: 663-88.

3. McNamara JO. Cellular and molecular basis of epilepsy. J Neurosci. 1994; 14: 3413-25.

4. Fanselow MS and Dong HW. Are the dorsal and ventral hippocampus functionally distinct structures? Neuron. 2010; 65: 7-19.

5. Papatheodoropoulos C, Moschovos C, and Kostopoulos G. Greater contribution of N-methyl-D-aspartic acid receptors in ventral compared to dorsal hippocampal slices in the expression and long-term maintenance of epileptiform activity. Neuroscience. 2005; 135: 765-79.

6.Ekstrand J, Pouliot W, Scheerlinck P, and Dudek FE. Lithium pilocarpine-induced status epilepticus in postnatal day 20 rats results in greater neuronal injury in ventral versus dorsal hippocampus. Neuroscience. 2011; 192:699-707.

7.Isaeva E, Romanov A, Holmes GL, and Isaev D. Status epilepticus results in region-specific alterations in seizure susceptibility along the hippocampal longitudinal axis. Epilepsy Res. 2015; 110: 166-70.

8. Papatheodoropoulos C, Asprodini E, Nikita I, and Koutsona C. W eaker synaptic inhibition in CA1 region of ventral compared to dorsal rat hippocampal slices. 2002; 117-21.

9.Gilbert M, Racine RJ, and Smith GK. Epileptiform burst responses in ventral vs dorsal hippocampal slices. Brain Res.1985; 361: 389-91.

10. Pandis C, Sotiriou E, Kouvaras E, Asprodini E, Papatheodoropoulos C, and Angelatou F. Differential expression of NMDA and AMPA receptor subunits in rat dorsal and ventral hippocampus. Neuroscience. 2006; 140: 163-75.

11. Walther H, Lambert JD, Jones RS, Heinemann U, and Hamon B. Epileptiform activity in combined slices of the hippocampus, subiculum and entorhinal cortex during perfusion with low magnesium medium. Neurosci Lett. 1986; 69: 156-61.

12. Mody I, Lambert JD, and Heinemann U. Low extracellular magnesium induces epileptiform activity and spreading depression in rat hippocampal slices. J Neurophysiol. 1987; 57: 869-88.

13. Jones RS and Heinemann U. Pre- and postsynaptic K+ and $\mathrm{Ca} 2+$ fluxes in area $\mathrm{CA} 1$ of the rat hippocampus in vitro: effects of Ni2+, TEA and 4-AP. Exp Brain Res. 1987; 68: 205-09.

14.Monyer H, Burnashev N, Laurie DJ, Sakmann B, and Seeburg PH, Developmental and regional expression in the rat brain and functional properties of four NMDA receptors. Neuron. 1994; 12: 529-40.

15.Sanchez RM and Jensen FE.Maturational Aspects of Epilepsy Mechanisms and Consequences for the Immature Brain. 2001; 577-85.

16. Weissinger F, Buchheim K, Siegmund H, Heinemann U, and Meierkord H.Optical imaging reveals characteristic seizure onsets, spread patterns, and propagation velocities in hippocampal-entorhinal cortex slices of juvenile rats. Neurobiol Dis. 2000; 7: 286-98.

17. Lewis DV, Jones LS, and Mott DD. Hippocampal epileptiform activity induced by magnesium-free medium: 
Effect of altered extracellular magnesium concentrations on the neuronal activity

differences between areas CA1 and CA2-3. Epilepsy Res. 1900; 6: 95-101.

18 Quilichini PP, Diabira D, Chiron C, Ben-Ari Y, and Gozlan H. Persistent epileptiform activity induced by low Mg2+ in intact immature brain structures. Eur J Neurosci. 2002; 16: $850-60$.

19. Coultrap SJ, Nixon KM, Alvestad RM, Valenzuela CF, and Browning MD, Differential expression of NMDA receptor subunits and splice variants among the CA1, CA3 and dentate gyrus of the adult rat. Brain Res Mol Brain Res.2005; 135: 104-11.

20. Dingledine R, Borges K, Bowie D, and Traynelis S. The glutamate receptor ion channels. Pharmacol Rev. 1999; 51: 7-61.

Received 20.09.2016 